\title{
A study of zinc-nickel alloy electrodeposition from an alkaline electrolyte
}

\author{
I.A. Adudin, (i) N.S. Grigoryan, (i) A.N. Serov, T.A. Vagramyan, (i)* \\ K.A. Orlova, M.A. Shelukhin ${ }^{\circledR}$ and V.Kh. Aleshina \\ Federal State-Funded Educational Institution of Higher Education "D. Mendeleev \\ University of Chemical Technology of Russia”, Miusskaya sq. 9, 125047 Moscow, \\ Russian Federation \\ *E-mail: vagramyan@muctr.ru
}

\begin{abstract}
An alkaline electrolyte with an amine-containing organic ligand (onwards L) for the electrodeposition of zinc-nickel alloy onto the surface of steel products with the aim of replacing the toxic cadmium-plating electrolyte has been developed. The electrolyte contains (mol/L): $\mathrm{Zn}^{2+} 0.07-0.14 ; \mathrm{Ni}^{2+} 0.03-0.06$; $\mathrm{L}$ (aliphatic amine-containing ligand) $0.1-$ $0.2, \mathrm{pH} 13-14, t=22^{\circ} \mathrm{C}$. The alloy composition remains constant at various mole ratios of $\mathrm{Ni} / \mathrm{L}$ in the electrolyte in a wide range of current densities. A coating containing $12-14 \% \mathrm{Ni}$ can be obtained from the electrolyte with a molar ratios $\mathrm{Ni} / \mathrm{L} 0.6$ and Ni/Zn 0.4. Such ratio produces a coating with the highest corrosion resistance while preserving the electrochemical character of protection of the steel base. The nickel content in the coating increases with an increase in the electrolyte temperature. In heated solutions with the total metal content of $0.2 \mathrm{~mol} / \mathrm{L}$, the increase of $\mathrm{Ni} / \mathrm{L}$ ratio in the electrolyte significantly increases the nickel content in the coating. In cold solutions such an increase is insignificant. At the total metal concentration of $0.1 \mathrm{~mol} / \mathrm{L}$ the increase of the molar ratio $\mathrm{Ni} / \mathrm{L}$ does not lead to such an apparent increase of nickel content in the coating. It has been determined that the developed zinc-nickel coatings in terms of protective ability and corrosion resistance are significantly superior to zinc coatings, and are comparable to cadmium coatings.
\end{abstract}

Keywords: electrodeposition, zinc-nickel alloy, $\mathrm{Zn}-\mathrm{Ni}$, alkaline electrolyte, corrosion protection, electroplating technology, surface treatment.

Received: February 12, 2021. Published: April 14, 2021

doi: $\underline{10.17675 / 2305-6894-2021-10-2-6}$

\section{Introduction}

Zinc coatings are used for corrosion protection of steel products and structures in different branches of the industry [1,2]. It is known that alloying zinc coatings with group 8 metals such as cobalt or nickel can significantly increase their corrosion resistance by shifting their potential into the positive region $[3,4]$.

The corrosion characteristics of the coating depend upon the nickel content, with the optimal nickel content in the coating being between 12 to 14\%. When the nickel content in the alloy is lower (below 12\%) the coating is unstable in saline environments, whereas when 
the nickel content is higher (above 14\%) - the coating becomes so electropositive that it loses the electrochemical character of corrosion protection. Such a coating is only able to protect the substrate mechanically [5].

Zinc-nickel coatings have a decorative appearance and, depending on the conditions of deposition, can be mate, semi-shiny or shiny. They do not undergo contact corrosion when in contact with aluminum and are stable in numerous hydraulic fluids [6]. They preserve their appearance longer then zinc coatings due to the fact that $\mathrm{Ni}$ passivizes them [7]. Compared with an ordinary zinc coating, a zinc-nickel coating retains its anti-corrosion properties during continuous operation at high temperatures (over $90^{\circ} \mathrm{C}$ ) [7-9]. $\mathrm{Zn}-\mathrm{Ni}$ alloy has greater hardness and microhardness, greater heat-resistance, but withstands less mechanical processing (deformation, stamping, flaring etc.).

The protective and decorative zinc-nickel coatings are widely used in automobile industry, in the factories of BMW, Audi, Fiat, Renault etc., as they can easily tolerate high operation temperatures $\left(100-160^{\circ} \mathrm{C}\right)$, realized in the engine compartment of cars in warm climates [10-12]. Currently about $60 \%$ of $\mathrm{Zn}-\mathrm{Ni}$ alloy coatings are used in the automobile industry, $10 \%$ - in power lines, $15 \%$ - in military equipment, $15 \%$ - for covering various fasteners and metal products in other industries.

The demand for zinc-nickel alloy coatings has increased since the adoption of the European directive in 2011 completely prohibiting the presence of toxic cadmium in the elements and structures of electrical and electronic equipment [13]. Since 2016, the use of cadmium in electrical and radio-electronic products has also been banned on the territory of the Russian Federation [14].

A variety of acidic and alkaline electrolytes for the deposition of zinc-nickel coatings had been investigated [15]. The main disadvantage of acidic electrolytes is their low scattering ability, the dependence of the alloy composition on the parameters of electrolysis and, as a result, its instability along the surface of a complexly shaped product, the complexity of adjusting the electrolyte, etc. [16]

Alkaline cyanide-free electrolytes, like cyanide ones, have a high scattering ability, which makes it possible to use these electrolytes to coat products with complex shapes. In addition to that, coatings obtained in an alkaline electrolyte have a higher corrosion resistance [17-19].

Currently, imported technologies based on alkaline electrolytes with the use of aminecontaining aliphatic compounds that form a strong complex with nickel ions are finding practical application in the Russian Federation [18]. ${ }^{1}$ Domestic developments in the field of zinc-nickel alloy deposition date back to the 80s and have not found a practical application, since they do not meet the high modern requirements for scattering power, stability and the electrolyte resource.

\footnotetext{
${ }^{1}$ On the basis of these amines, a large class of inhibitors is produced to combat corrosion. For example, an aliphatic amine-containing polymer - L with a molecular weight of not more than 2000 units is an effective inhibitor of corrosion of steel and copper [19]. It inhibits steel corrosion in a wide temperature range (20$90^{\circ} \mathrm{C}$ ) with a high degree of protection (over $93 \%$ ).
} 
This study is devoted to the development of a technology for applying protective and decorative galvanic zinc-nickel coatings from an alkaline electrolyte onto the steel surface.

\section{Experimental}

Plates made of $08 \mathrm{ps}$ steel with the size of $2 \times 2.5 \mathrm{~cm}$ were used as samples.

The solutions were prepared using chemical reagents of the "pure" and "pure grade" brands and distilled water.

The electrolyte for alloy deposition was prepared as follows:

- $\mathrm{ZnO}$ and $\mathrm{NaOH}$ in a ratio of about 1:10 were mixed dry, then dissolved in water $(0.5-$ 0.6 parts of the total volume);

- $\mathrm{NiSO}_{4} \cdot 7 \mathrm{H}_{2} \mathrm{O}$ was dissolved in a separate portion of water $(0.1$ part of the total volume); aliphatic amine-containing polymer (AAP) with a molecular weight of not more than 2000 units was dissolved in water ( 0.25 parts of the total volume); nickel sulphate previously dissolved in water $\left(\mathrm{NiSO}_{4} \cdot 7 \mathrm{H}_{2} \mathrm{O}\right)$ was added to solution $\mathrm{L}$;

- a solution of $\mathrm{NiSO}_{4} \cdot 7 \mathrm{H}_{2} \mathrm{O}$ and AAP were added to the zincate solution, after which the volume was adjusted with distilled water.

The alkalinity of the prepared solution was $13-14 \mathrm{pH}$ units.

The developed coatings were compared in terms of their characteristics with cadmium and zinc ones, which were deposited from standard cadmium and zinc solutions in accordance with [20] and [21].

To measure the $\mathrm{pH}$ of the solution, we used a pH-410 pH-meter with an ESK-10603 combined glass electrode.

The cathodic current efficiency of the alloy was determined using a copper coulometer and calculated according to the formula [22]:

$$
C E=\frac{\Delta m_{\mathrm{alloy}} \cdot q_{\mathrm{Cu}}}{\Delta m_{\mathrm{Cu}} \cdot q_{\mathrm{alloy}}} \cdot 100 \%,
$$

$q_{C u}, q_{\text {alloy }}$ - being the electrochemical equivalents of copper and alloy, respectively, $\mathrm{g} /(\mathrm{A} \cdot \mathrm{h})$; $\Delta m_{\mathrm{Cu}}, \Delta m_{\text {alloy }}$ - the weight gain of the coulometer cathode and sample, respectively, $\mathrm{g}$.

The chemical composition of the coating was studied by X-ray fluorescence spectrometry using an EDX-7000 energy dispersive spectrometer (Shimadzu, Japan).

The method is based on the correlation between the intensity of X-ray fluorescence of a chemical element and its concentration in the coating. When a sample is irradiated with a powerful X-ray flux, characteristic fluorescent radiation of atoms arises, the intensity of which is proportional to their concentration in the sample. The radiation is decomposed into a spectrum using analyser crystals, then its intensity is measured using detectors and computational electronics.

The permissible range of current densities, in which high quality zinc-nickel coatings are deposited, were determined using a Hull corner cell (Figure 1). 
Steel plates with the dimensions of $100 \times 70 \times 0.7 \mathrm{~mm}$ were used as cathodes, a nickel plate served as an anode.
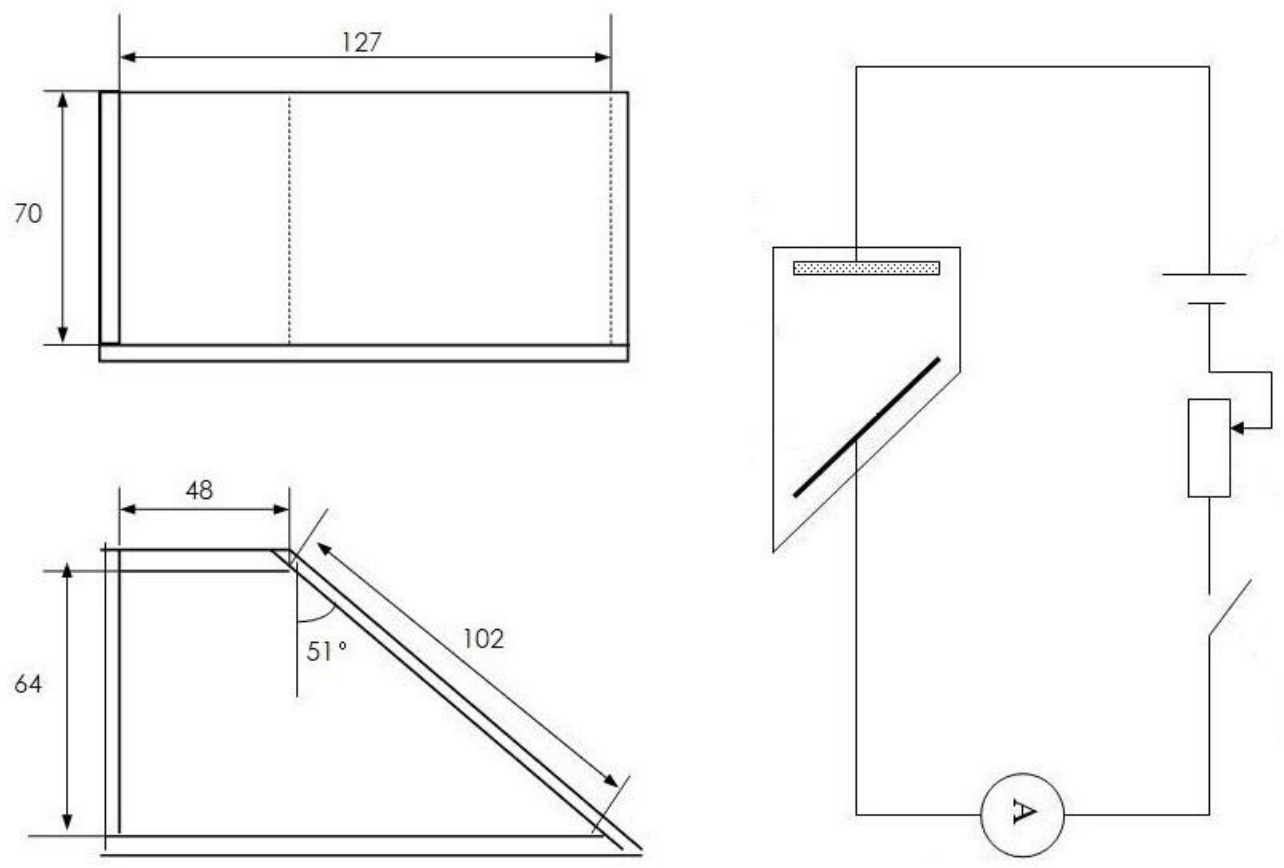

Figure 1. Image and wiring diagram for Hull corner cell.

Corrosion tests were carried out in an Ascott S450iP salt fog chamber in accordance with the international standard ASTM B117 [19]. Samples with a zinc-nickel coating of $10 \mu \mathrm{m}$ thickness without subsequent passivation were tested.

\section{Results and Discussion}

When choosing a ligand for the developed electrolyte, we proceeded from the fact that it should form stronger complexes with the positive component of the alloy, i.e., nickel, so that its content in the alloy would be low or, more precisely, would be in the range of $12-14 \%$, thus providing a coating with the maximum corrosion resistance while maintaining the electrochemical nature of protection of the steel base.

Literature analysis has shown that an amine-containing organic ligand (L) with a molecular weight of not more than 2000 units could be suitable for the alkaline electrolyte.

The stability constants $\left(\lg K_{\text {st }}\right)$ of zinc and nickel complexes with $\mathrm{L}$, as well as the zincate complex at $\mathrm{pH}$ of $13-14$ according to $[23]$ are: $\left[\mathrm{Zn}(\mathrm{OH})_{4}\right]^{2-} 17.7,\left[\mathrm{NiL}_{2}\right]^{2+} 18.6,\left[\mathrm{ZnL}_{2}\right]^{2+}$ 12.03. Since nickel is not an amphoteric metal, it does not form complexes with $\mathrm{OH}^{-}$ions.

The comparison of strengths of the given zinc and nickel complexes suggests that when the zinc-nickel alloy is deposited from an alkaline electrolyte, nickel will be discharged from the amine complex, and zinc - from the zincate one. During this the discharge of nickel will be more difficult than that of zinc, which will make it possible to obtain an alloy of the required composition. 
The correlation between the alloy composition and the molar ratio $\mathrm{Ni}^{2+} / \mathrm{Zn}^{2+}$ and $\mathrm{Ni}^{2+} / \mathrm{L}$ in the electrolyte is studied at different total concentrations of metal ions and at different temperatures.

The studied electrolyte contained: mol-ion/ $\mathrm{L}: \mathrm{Zn}^{2+} 0.07-0.14 ; \mathrm{Ni}^{2+} 0.03-0.06 ; \mathrm{L} 0.1-$ $0.2, \mathrm{pH} 13-14$, temperature 22 and $50^{\circ} \mathrm{C}$.

As can be seen from the data Table 1 , at room temperature good quality coatings that meet the nickel content requirements $(12 \%)$ are deposited at $\mathrm{Ni}^{2+} / \mathrm{Zn}^{2+}$ and $\mathrm{Ni}^{2+} / \mathrm{L}$ ratios in the electrolyte equal to 0.4 and 0.6 , respectively. The total concentration of metal ions is $0.2 \mathrm{~mol}-\mathrm{ion} / \mathrm{L}$.

Table 1. The correlation between the nickel content in the coating and the molar ratios of $\mathrm{Ni}^{2+} / \mathrm{Zn}^{2+}$ and $\mathrm{Ni}^{2+} / \mathrm{L}$ at the temperature of $22^{\circ} \mathrm{C}$.

\begin{tabular}{cccc}
\hline & \multicolumn{3}{c}{$\mathbf{N i}^{2+} / \mathbf{L}$ molar ratio } \\
\cline { 2 - 4 } $\mathbf{N i}^{2+} / \mathbf{Z n}^{2+}$ molar ratio & $\begin{array}{c}\mathbf{0 . 3} \\
(\mathbf{0 . 0 6} \mathbf{~ N i}, \mathbf{0 . 2} \mathbf{~ L})\end{array}$ & $\begin{array}{c}\mathbf{0 . 4} \\
\mathbf{( 0 . 0 6} \mathbf{~ N i}, \mathbf{0 . 1 4} \mathbf{L})\end{array}$ & $\begin{array}{c}\mathbf{0 . 6} \\
(\mathbf{0 . 0 6} \mathbf{~ N i}, \mathbf{0 . 1} \mathbf{~ L})\end{array}$ \\
\hline $\begin{array}{c}0.3 \\
(0.06 \mathrm{Ni}, 0.2 \mathrm{Zn})\end{array}$ & $\begin{array}{c}\text { Decomposition of } \\
\text { the electrolyte }\end{array}$ & 7 & 11 \\
\hline 0.4 & 8 & 10 & 13 \\
\hline$(0.06 \mathrm{Ni}, 0.14 \mathrm{Zn})$ & 9 & 10 & $\begin{array}{c}\text { Decomposition of the } \\
\text { electrolyte }\end{array}$ \\
\hline $\begin{array}{c}0.6 \\
(0.06 \mathrm{Ni}, 0.1 \mathrm{Zn})\end{array}$ & & & \\
\hline
\end{tabular}

Figure 2 shows the correlation between the alloy composition and the molar ratio of $\mathrm{Ni}^{2+} / \mathrm{L}$ in solution with a total content of metal ions in solution of 0.1 and $0.2 \mathrm{~mol} / \mathrm{L}$ (Figure $2 \mathrm{a}$ and $\mathrm{b}$, respectively) with the retention of the ratio $\mathrm{Ni}^{2+} / \mathrm{Zn}^{2+} 0.4$ at a temperature of 22 and $50^{\circ} \mathrm{C}$. The dotted lines in the figure show the range of the values of the nickel content in the coating (12-14\%), which corresponds to its best corrosion characteristics.

It can be seen that, in all cases, with an increase in the $\mathrm{Ni}^{2+} / \mathrm{L}$ ratio in solution, the nickel content in the coating increases, which is apparently explained (taking into account the Le Chatelier rule) by a decrease in the stability of the complexes as the amount of free ligand decreases in accordance with the equilibrium:

$$
\left[\mathrm{NiL}_{2}\right]^{2+} \rightleftarrows \mathrm{Ni}^{2+}+2 \mathrm{~L}^{-}
$$

This is indirectly confirmed by a more significant increase in the nickel content in the coating as a result of the increase in the $\mathrm{Ni}^{2+} / \mathrm{L}$ ratio in the solution with the total metal ion content of $0.2 \mathrm{~mol} / \mathrm{L}$, i.e. in a solution with a higher concentration of nickel ions.

The increase in nickel content in the alloy observed in all cases when the solution is heated to $50^{\circ} \mathrm{C}$ is most likely due to the fact that as the temperature rises, the electrochemical reduction of nickel becomes easier, which is not typical for the electroreduction of zinc [24]. 
In addition, according to [25], the stability of the nickel amine complex decreases with increasing temperature, which also contributes to an increase in the nickel content in the alloy.
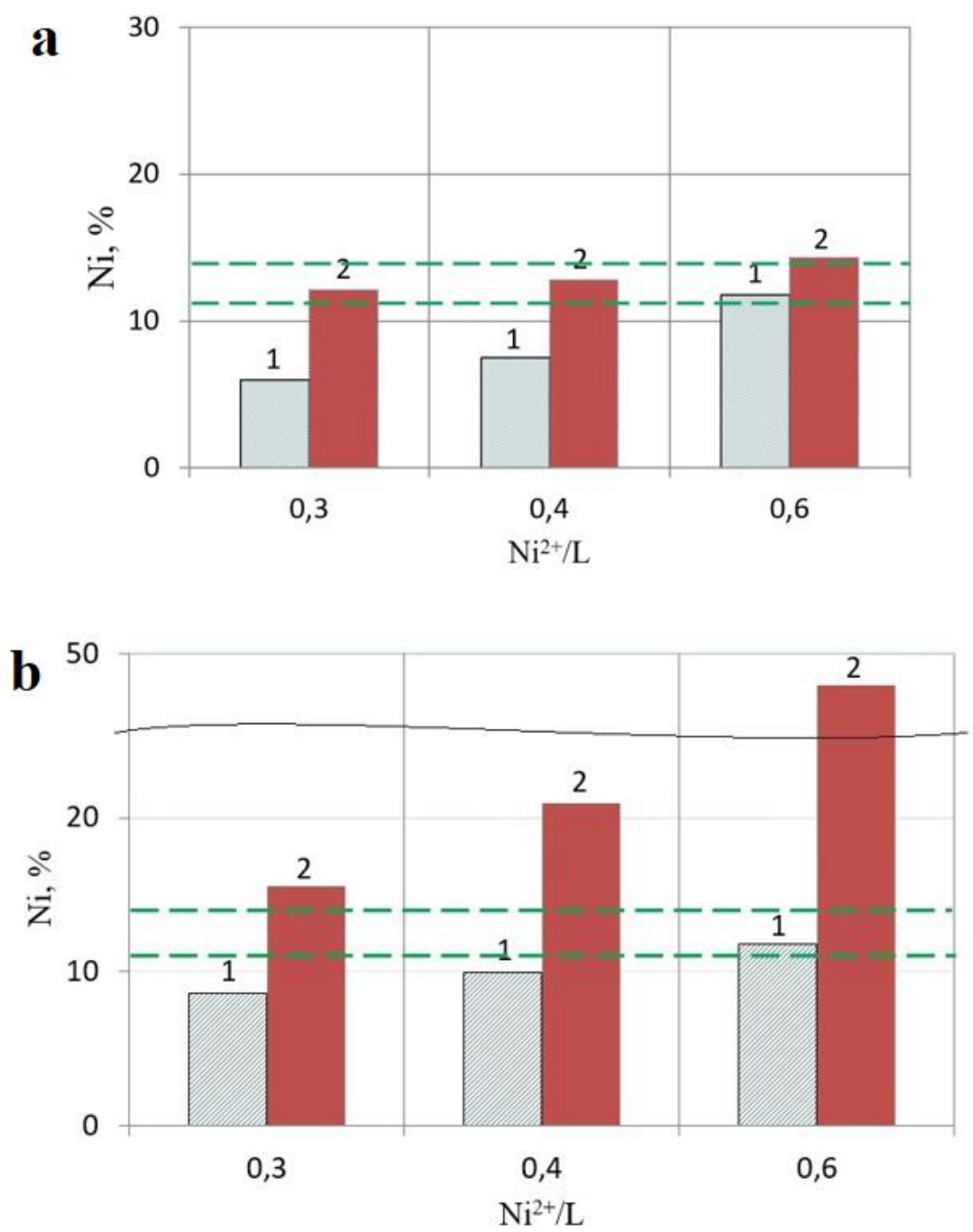

Figure 2. The correlation between the nickel content in the coating and the molar ratio $\mathrm{Ni}^{2+} / \mathrm{L}$ in solution with the total metal content of $0.1 \mathrm{~mol} / \mathrm{L}$ (a) and $0.2 \mathrm{~mol} / \mathrm{L} \mathrm{(b)}, \mathrm{pH}=13$; $i_{\mathrm{c}}=1 \mathrm{~A} / \mathrm{dm}^{2} ; 1 . t=22^{\circ} \mathrm{C} ; 2 . t=50^{\circ} \mathrm{C}$.

At the molar ratio of $\mathrm{Ni}^{2+} / \mathrm{Zn}^{2+} 0.4$, the molar ratio of $\mathrm{Ni}^{2+} / \mathrm{L} 0.6$ and the temperature of $22^{\circ} \mathrm{C}$, the coatings containing $12-14 \%$ nickel can be deposited from both a solution with the total metal content of $0.1 \mathrm{~mol} / \mathrm{L}$ and a solution with the total metal content of $0.2 \mathrm{~mol} / \mathrm{L}$. At the temperature of $50^{\circ} \mathrm{C}$, the coatings of the required composition are deposited in a wider range of $\mathrm{Ni}^{2+} / \mathrm{L}$ ratios $(0.3,0.4$ and 0.6$)$, but only from a solution with the total content of metal ions of $0.1 \mathrm{~mol} / \mathrm{L}$.

The diagrams shown in Figure 3 indicate that, with the increase in the solution temperature, the cathodic current efficiency significantly decreases in the entire studied 
range of the $\mathrm{Ni}^{2+} / \mathrm{L}$ ratios, and this decrease is greater, the lower is the ligand content in the solution. This is due to the lower overvoltage of hydrogen evolution on nickel (as compared to zinc), the content of which increases in the alloy with an increase in the $\mathrm{Ni}^{2+} / \mathrm{L}$ ratio in solution. The diagrams are similar for a solution with the total content of metal ions of $0.1 \mathrm{~mol} / \mathrm{L}$.

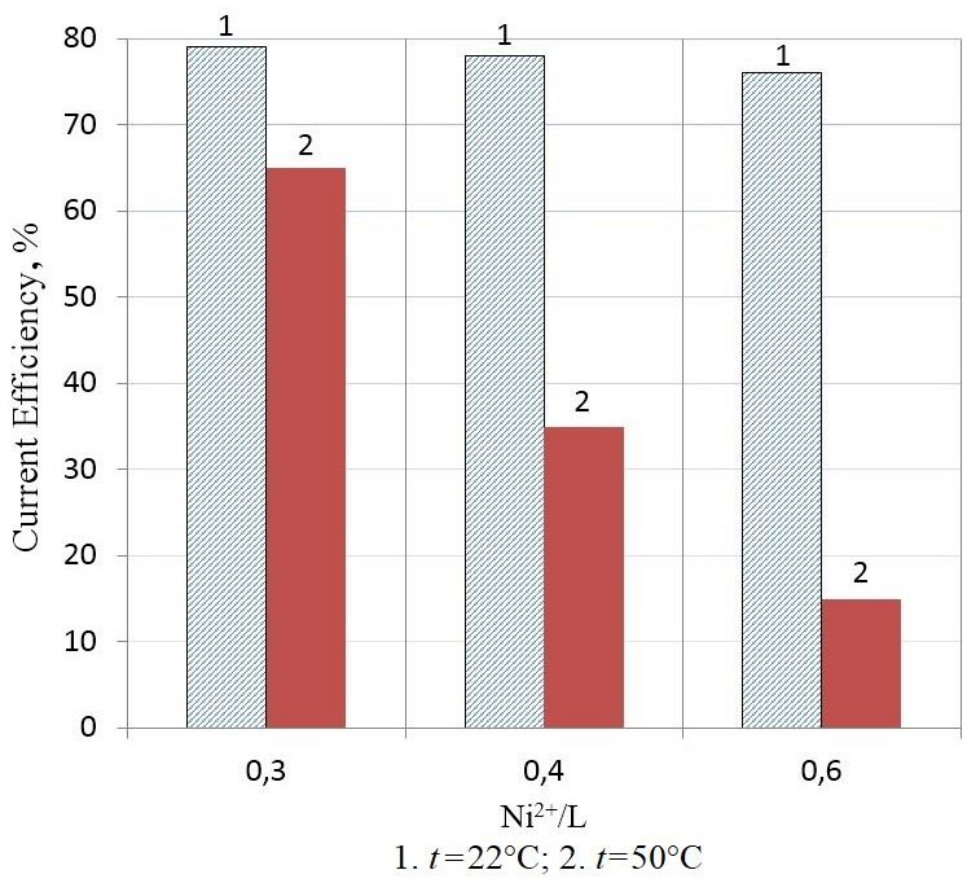

Figure 3. The correlation between the cathodic current efficiency and the molar ration $\mathrm{Ni} / \mathrm{L}$ at various temperatures. $\left(\mathrm{Zn}^{2+} 0.14 \mathrm{~mol} / \mathrm{L} ; \mathrm{Ni}^{2+} 0.06 \mathrm{~mol} / \mathrm{L} ; \mathrm{pH}=13 ; i_{\mathrm{c}}=1 \mathrm{~A} / \mathrm{dm}^{2}\right)$; total metal content $0.2 \mathrm{~mol} / \mathrm{L}$.

Considering that the required composition and quality of the coating can be achieved at the electrolyte temperature of $22^{\circ} \mathrm{C}$, and heating the solution not only does not provide technologically significant advantages, but, on the contrary, leads to a decrease in the process efficiency due to a decrease in the cathode current efficiency and additional electricity costs, further research were carried out at the temperature of $22^{\circ} \mathrm{C}$.

It should be noted that the above-mentioned experiments were carried out at the cathode current density of $1 \mathrm{~A} / \mathrm{dm}^{2}$. Further, the correlation between the alloy composition and the cathode current density and the correlation between the current efficiency and cathode current density were studied.

The results presented in Figure 4 show that when the total content of nickel and zinc ions in the solution is equal to $0.1 \mathrm{~mol} / \mathrm{L}$ and the $\mathrm{Ni}^{2+} / \mathrm{L}$ ratio is equal to 0.6 , the alloys with the nickel content of $12-14 \%$ are deposited in the current density range: $1.0-5.0 \mathrm{~A} / \mathrm{dm}^{2}$ (Figure 4a). When increasing the total content of metal ions in the solution to $0.2 \mathrm{~mol} / \mathrm{L}$, the range of permissible current densities expands towards lower values and is: $0.2-5.0 \mathrm{~A} / \mathrm{dm}^{2}$ (Figure 4b). 

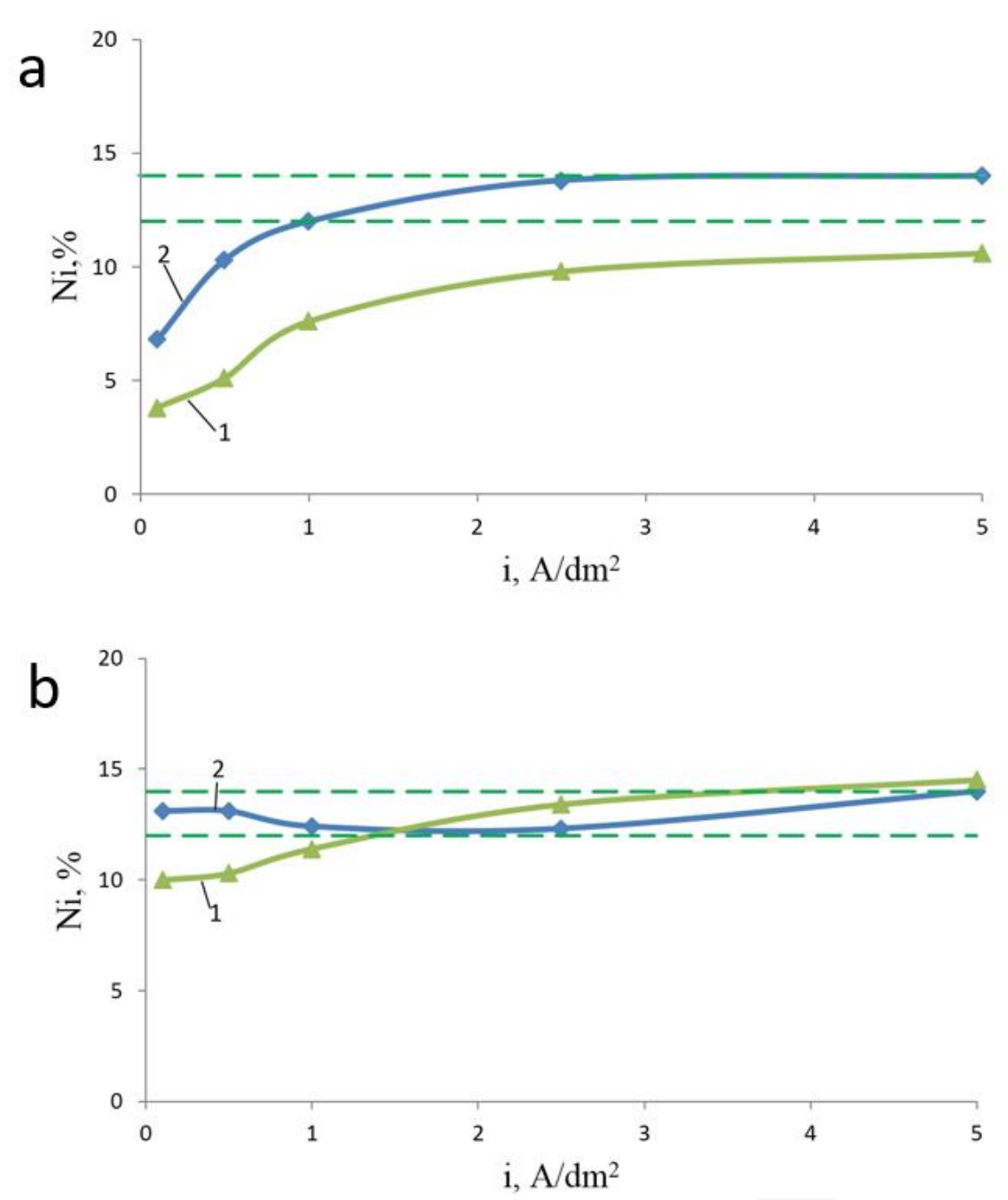

Figure 4. The correlation between the content of nickel in the coating and the cathode current density at various molar ratios $\mathrm{Ni} / \mathrm{L}$ and the total concentration of metals $0.1 \mathrm{~mol} / \mathrm{L}$ (a) and $0.2 \mathrm{~mol} / \mathrm{L}$ (b). $1 . \mathrm{Ni}^{2+} / \mathrm{L} 0.3 ; 2 . \mathrm{Ni}^{2+} / \mathrm{L} 0.6 ; \mathrm{pH}=13-14 ; t=20-25^{\circ} \mathrm{C}$.

Since the entire range of current densities is realized on a complex-shaped product, and extremely low current densities (up to $0.2 \mathrm{~A} / \mathrm{dm}^{2}$ ) can be realized in areas far from the anode of the surface of this product, the electrolyte with a $\mathrm{Ni}^{2+} / \mathrm{L}$ molar ratio of 0.6 and the total concentration of metals is $0.2 \mathrm{~mol} / \mathrm{L}$ should be considered optimal.

The observed constancy of the alloy composition in a wide range of operating electrolyte current densities is a positive technological factor that will ensure the uniformity of the chemical composition of the alloy and, consequently, the uniformity of its physical and mechanical properties on the surface of a complex-shaped product.

As can be seen from in dependencies shown in Figure 5, an increase in the cathode current density in the operating range decreases the current efficiency from 80 to $40 \%$ or from 60 to $10 \%$, depending on the total content of metal ions in the solution. This character of correlation between the cathode current efficiency and the current density, as is known, contributes to the uniformity the coating's thickness of a complexly shaped base [22]. 


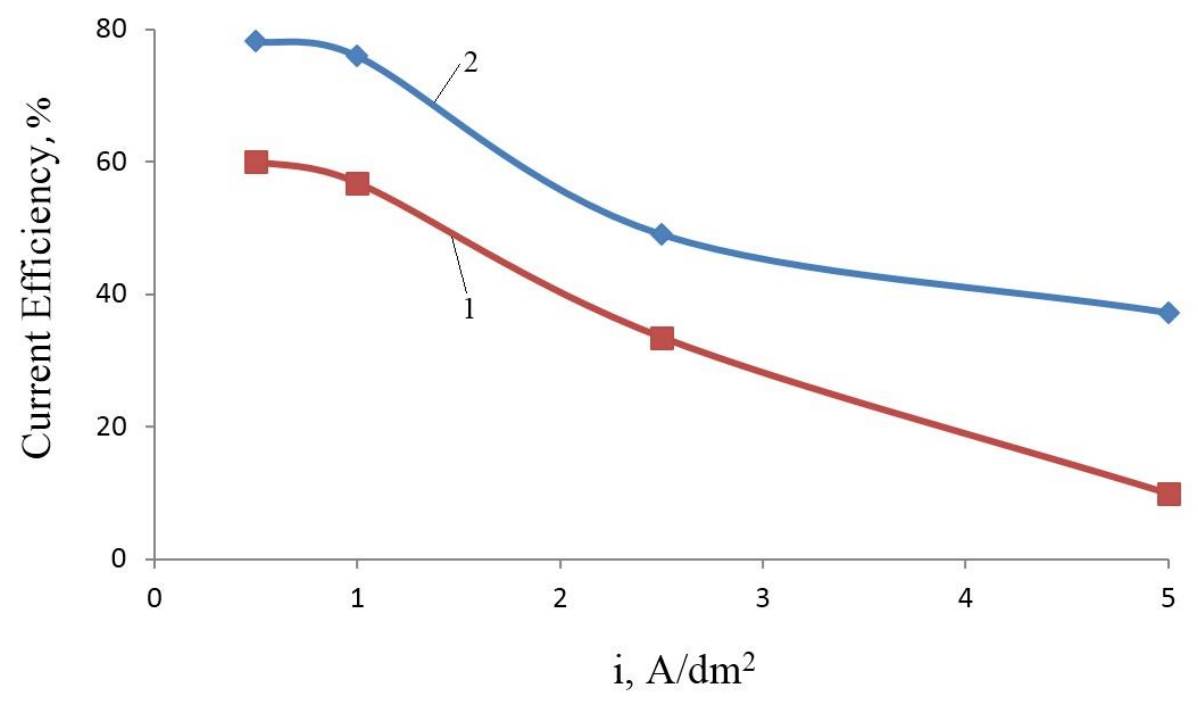

Figure 5. The correlation between the cathode current efficiency of the alloy and the current density in the electrolyte with the $\mathrm{Ni} / \mathrm{L}$ molar ratio of 0.6 and the total concentration of metals: $0.1 \mathrm{~mol} / \mathrm{L}(1) ; 0.2 \mathrm{~mol} / \mathrm{L}(2)$.

Taking into account the results obtained, the optimal composition of the electrolyte and the parameters of the process of the deposition of the zinc-nickel coating containing 1214\% Ni were selected (Table 2).

Table 2. Optimal electrolyte composition and process parameters.

\begin{tabular}{cc}
\hline Component, parameter & Concentration, $\mathbf{~ m o l} / \mathbf{L}$ \\
\hline $\mathrm{Zn}^{2+}$ & 0.14 \\
$\mathrm{Ni}^{2+}$ & 0.06 \\
$\mathrm{~L}$ & 0.1 \\
$\mathrm{pH}$ & $13-14$ \\
$t$ & $22-25^{\circ} \mathrm{C}$ \\
$i_{\mathrm{c}}$ & $0.1-5 \mathrm{~A} / \mathrm{dm}^{2}$ \\
\hline
\end{tabular}

Corrosion diagrams of zinc, cadmium and zinc-nickel coatings (deposited from the developed electrolyte) onto a steel base in a 3\% (mass) $\mathrm{NaCl}$ solution were obtained and the corrosion currents values were determined. Polarization measurements were performed using an IPC-Micro potentiostat in an electrochemical cell. Steel plates with zinc, zincnickel and cadmium coatings were used as the working electrode, nickel, cadmium and zinc plates were used as the auxiliary electrode. A standard silver chloride electrode served as the reference electrode. The measurement results were recalculated with respect to the standard hydrogen electrode. Polarization curves were recorded in the potentiodynamic mode at a rate of $1 \mathrm{mV} / \mathrm{s}$. From the results provided in Table 3 it can be seen that the protective ability of 
the zinc-nickel coatings is 4 times higher than that of zinc and is somewhat inferior to that of cadmium coatings.

Table 3. Corrosion characteristics of coatings.

\begin{tabular}{ccc}
\hline Coating & $\boldsymbol{I}_{\mathbf{c o r r}}, \boldsymbol{\mu} \mathbf{A} / \mathbf{c m}^{\mathbf{2}}$ & $\boldsymbol{E}_{\text {corr, }} \mathbf{V}$ \\
\hline $\mathrm{Cd}$ & 8 & -0.770 \\
$\mathrm{Zn}-\mathrm{Ni}$ & 9 & -0.886 \\
$\mathrm{Zn}$ & 35 & -0.943 \\
\hline
\end{tabular}

It has been determined that the zinc-nickel coating can withstand 120 hours in a salt fog chamber (ASTM B117, ISO 9227) before the formation of the first white corrosion spots on its surface, which is significantly higher than that of the zinc coating (10 hours). The time before the appearance of the first foci of red corrosion on the zinc-nickel coating is 450 hours, which is also significantly higher than that of the zinc coating (150 hours). The time until the first foci of white and red corrosion appears on the cadmium coating is 160 and 470 hours, respectively, which is slightly higher than for zinc-nickel coatings (Figure 6).

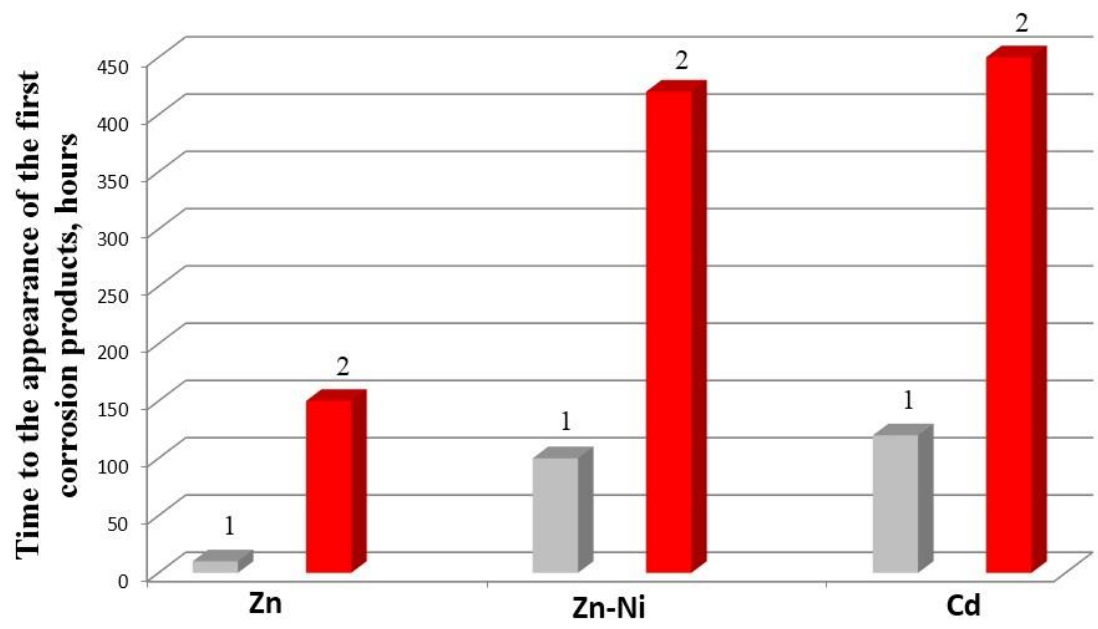

1 - white corrosion; 2 - red corrosion

Figure 6. Corrosion test results in a salt fog chamber.

Thus, the developed electrolyte contains $0.14 \mathrm{~mol} / \mathrm{L} \mathrm{Zn}^{2+}, 0.06 \mathrm{~mol} / \mathrm{L} \mathrm{Ni}^{2+}$, $0.1 \mathrm{~mol} / \mathrm{L} \mathrm{L}$, allowing to deposition of a zinc-nickel coating at the $\mathrm{pH}$ of $13-14, t=20$ $25^{\circ} \mathrm{C}, i_{\mathrm{c}} 0.1-5 \mathrm{~A} / \mathrm{dm}^{2}$ onto the steel surface. These coatings containing $12-14 \%$ nickel are superior to zinc ones in terms of their protective ability and corrosion resistance and are slightly inferior to cadmium coatings. 


\section{Acknowledgements}

The work was supported by the Mendeleev University of Chemical Technology of Russia. Project Number X-2020-027.

\section{References}

1. C.M. Praveen Kumar, T.V. Venkatesha, K. Vathsala and K.O. Nayana, Electrodeposition and corrosion behavior of $\mathrm{Zn}-\mathrm{Ni}$ and $\mathrm{Zn}-\mathrm{Ni}-\mathrm{Fe}_{2} \mathrm{O}_{3}$, J. Coat. Technol. Res., 2012, 9, 71-77. doi: 10.1007/s11998-011-9322-5

2. M. Paunovic and M. Schlesinger, Modern Electroplating, Pennington, NJ, Electrochemical Society, 2010.

3. V.V. Okulov, Zinc plating. Technique and technology, Moscow, Globus, 2008, 252 pp. (in Russian).

4. G.D. Wilcox and D.R. Gabe, Electrodeposited zinc alloy coatings, Corros. Sci., 1993, 35, 1251-1258. doi: $10.1016 / 0010-938 X(93) 90345-\mathrm{H}$

5. K.R. Baldwin, M.J. Robinson and C.J.E. Smith, The corrosion resistance of electrodeposited zinc-nickel alloy coatings, Corros. Sci., 1993, 35, 1267-1272. doi: 10.1016/0010-938X(93)90347-J

6. E. Baptishta, P. Praykshat, M. Ryosh and A.N. Serov, Zashchitnyie pokrytiya splavom tsink-nikel' (Protective zinc-nickel coatings), Gal'vanotehnika i obrabotka poverhnosti, 2012, 20, no. 1, 29-31 (in Russian).

7. V.I. Mamayev and V.N. Kudryavcev, Nickel plating, Moscow, D. Mendeleyev University, 2014, 192 pp. (in Russian).

8. S. Fashu, C.D. Gu, X.L. Wang and J.P. Tu, Influence of electrodeposition conditions on the microstructure and corrosion resistance of $\mathrm{Zn}-\mathrm{Ni}$ alloy coatings from a deep eutectic solvent, Surf. Coat. Technol., 2014, 242, 34-41. doi: 10.1016/j.surfcoat.2014.01.014

9. M. Ishihara, H. Yumoto, K. Akashi and K. Kamei, Zinc-nickel alloy whiskers electrodeposited from a sulfate bath, Mater. Sci. Eng.: B, 1996, 38, 150-155. doi: 10.1016/0921-5107(95)01429-2

10. X. Wen, Z. Yang, X. Xiao, H. Yang, X. Xie and J. Huang, The Impact of Hydrocalumites Additives on the Electrochemical Performance of Zinc-Nickel Secondary Cells, Electrochim. Acta, 2016, 187, 65-72. doi: 10.1016/j.electacta.2015.11.046

11. M. Kwon, D-h. Jo, S.H. Cho, H.T. Kim, J-T. Park and J.M. Park, Characterization of the influence of $\mathrm{Ni}$ content on the corrosion resistance of electrodeposited $\mathrm{Zn}-\mathrm{Ni}$ alloy coatings, Surf. Coat. Technol., 2016, 288, 163-170. doi: 10.1016/j.surfcoat.2016.01.027

12. X. Qiaoa, H. Li, W. Zhaoa and D. Li, Effects of deposition temperature on electrodeposition of zinc-nickel alloy coatings, Electrochim. Acta, 2013, 89, 771-777. doi: $\underline{10.1016 / \text { j.electacta.2012.11.006 }}$ 
13. Directive 2011/65/EU (RoHS II) of European Parliament and Council of 8 June 2011 on the restriction of the use of certain hazardous substances in electrical and electronic equipment.

14. Technical Regulations of the Eurasian Economic Community "On the Restriction of the Use of Hazardous Substances of Electrical and Electronic Products" (TR EAEU 037/2016) (approved by the Council of the Eurasian Economic Commission on October 18, 2016 (No. 113)).

15. X. Qiaoa, H. Li, W. Zhaoa and D. Li, Effects of deposition temperature on electrodeposition of zinc-nickel alloy coatings, Electrochim. Acta, 2013, 89, 771-777. doi: 10.1016/j.electacta.2012.11.006

16. R. Kraus, Kislyi ili shchelochnoi tsink-nikel'? Sistemnoe sravnenie (Acidic or alkaline zinc-nickel? Systematic comparison), Gal'vanotehnika i obrabotka poverhnosti, 2013, 21, no. 4, 24-29 (in Russian).

17. N. Lotfi, M. Aliofkhazraei, H. Rahmani and Gh. Barati Darband, Zinc-Nickel Alloy Electrodeposition: Characterization, Properties, Multilayers and Composites, Prot. Met. Phys. Chem. Surf., 2018, 54, 1102-1140. doi: 10.1134/S2070205118060187

18. R.M. Smith and A.E. Martell, Critical stability constants, Volume 2: Amines, New York, Plenum Press, 1974, 2, 416 pp.

19. V.S. Sastri, Green corrosion inhibitors: theory and practice, 1935, $310 \mathrm{pp}$.

20. GOST 9.305-84, Unified corrosion and aging protection system. Metallic and nonmetallic coatings. Technological processes for the manufacture of coatings, House of standards, 2003 (in Russian).

21. A.A. Abrashov, N.S. Grigoryan, E.A. Zheludkova, T.A. Vagramyan and N.A. Asnis, Silicon-containing solution for passivation of zinc coatings, Russ. J. Appl. Chem., 2019, 92, no. 10, 1432-1438. doi: 10.1134/S1070427219100136

22. N.G. Bahchnsaraycyan, Yu.V. Borisoglebskiy and G.K. Bukrat, Practical work on applied electrochemistry: Textbook for universities, Leningrad, Khimiya, 1990, 304 pp. (in Russian).

23. ASTM B.117-11, Standard Practice for Operating Salt Spray (Fog) Apparatus.

24. N.T. Kudryavcev, K.M. Tyunina and S.M. Figner, Elektroliticheskoe osazhdenie splavom tsink-nikel' dlya zashchity ot korrozii (Electrolitic zinc-nickel coating for corrosion protection of steel products), Zhurnal prikladnoi khimii, 1962, no. 5, 10351043 (in Russian).

25. A.E. Martell and R.M. Smith, Critical Stability Constants, Volume 2: Amines, Plenum Press, 1982, 426 pp.

26. A. Gergely, I. Sóvágó, I. Nagypaál and R. Király, Equilibrium relations of alphaaminoacid mixed complexes of transition metal ions, Inorg. Chim. Acta, 1972, 6, 435439. doi: $10.1016 / \mathrm{S} 0020-1693(00) 91832-2$ 